\title{
Intra-specific responses of Cymodocea nodosa to macro-nutrient, irradiance and copper exposure
}

\section{Papathanasiou, V}

http://hdl.handle.net/10026.1/3914

\subsection{6/j.jembe.2015.04.022 \\ Journal of Experimental Marine Biology and Ecology}

All content in PEARL is protected by copyright law. Author manuscripts are made available in accordance with publisher policies. Please cite only the published version using the details provided on the item record or document. In the absence of an open licence (e.g. Creative Commons), permissions for further reuse of content should be sought from the publisher or author. 


\title{
Intra-specific responses of Cymodocea nodosa to macro-nutrient, irradiance and copper exposure
}

\author{
Vasillis Papathanasiou a, ${ }^{\mathrm{a}}$, Sotiris Orfanidis ${ }^{\mathrm{a}}$, Murray T. Brown ${ }^{\mathrm{b}}$ \\ a Fisheries Research Institute, ELGO Dimitra, Benthic Ecology \& Technology Lab, Nea Peramos, Kavala 64007, Greece \\ b School of Marine Science and Engineering, University of Plymouth, Drake Circus, Plymouth PL4 8AA, UK
}

\section{A R T I C L E I N F O}

Article history:

Received 16 September 2014

Received in revised form 17 April 2015

Accepted 24 April 2015

\section{Keywords:}

Seagrass

Factorial experiments

PAM-fluorescence

Leaf elongation

Mixed effects models

\begin{abstract}
A B S T R A C T
Excess macro-nutrients, metal contamination and light limitation are three of the most commonly encountered anthropogenic stressors affecting seagrass meadows. In this study, the effects of different combinations of nutrients $\left(\mathrm{N}-\mathrm{NO}_{3}, \mathrm{P}_{-} \mathrm{PO}_{4}\right)$, copper and irradiance were investigated in shoots of Cymodocea nodosa collected from three meadows in the N. Aegean Sea, one (Nea Karvali) impacted by anthropogenically-derived environmental stressors and two in more pristine condition (Thasos, Brasidas). In a series of laboratory experiments, shoots were exposed to varying nutrient and heavy metal concentrations, as well as varying irradiance levels, for 8 days and the effective quantum yield $\left(\Delta \mathrm{F} / \mathrm{Fm}^{\prime}\right)$ and leaf elongation were quantified. Results showed that C. nodosa increased $\Delta \mathrm{F} / \mathrm{Fm}^{\prime}$ under high nutrient concentrations $\left(30 \mu \mathrm{M} \mathrm{N}-\mathrm{NO}_{3}-2 \mu \mathrm{M} \mathrm{P}-\mathrm{PO}_{4}^{3-}\right)$ but significant differences were only apparent in shoots collected from the oligotrophic-less stressed meadows. Irradiance affected $\Delta \mathrm{F} / \mathrm{Fm}^{\prime}$ significantly in all shoots irrespective of source and $\mathrm{PO}_{4}-\mathrm{P}$ concentration, while higher values were measured under low light conditions and it was identified as the main pathway of eutrophication stress in N. Aegean Cymodocea meadows. Shoots, independently of acclimation were tolerant to copper enrichment, with only the highest copper concentrations (4.7 and $7.9 \mu \mathrm{M})$ having significant negative effects on $\Delta \mathrm{F} / \mathrm{Fm}$ '. Shoots from the more pristine meadows were less affected by $\mathrm{Cu}$ than those from the highly stressed meadow.
\end{abstract}

(C) 2015 Elsevier B.V. All rights reserved.

\section{Introduction}

Seagrass meadows are sensitive ecosystems that show variations in their distribution both seasonally and spatially (Boudouresque et al., 2009a). Natural factors such as the creation of gaps during winter storms, disease and herbivory can alter their distribution (Walker et al., 2006), as can human activities resulting from the expansion of populations living adjacent to estuaries and coastal waters. In some extreme cases anthropogenic stressors have led to the complete loss of meadows (Orth et al., 2006). Of particular concern to seagrasses are those environmental stressors that alter the quality and clarity of the water, such as nutrient and sediment inputs from runoff and sewage disposal, upland development, dredging, chemical pollution derived from industrial and agriculture practices and aquaculture (Short and Wyllie-Echeverria, 1996).

To develop effective planning procedures for the conservation of these valuable ecosystems, it is vital that an understanding of the response mechanisms to anthropogenic stressors be established. However, studies that have investigated the effects of and responses

\footnotetext{
* Corresponding author at: 35-37 Palaion Fokon Str., 54454 Thessaloniki, Greece Tel.: + 306945874855 .

E-mail address: vpapathanasiou@hotmail.com (V. Papathanasiou).
}

to a range of environmental stressors in seagrasses have yielded varying and often conflicting results. Different responses to nutrient enrichment both in the water column and the sediment (i.e. positive, negative and none) have been observed in different species, and also within species from different biogeographical regions (Ceccherelli and Cinelli, 1997; Lee et al., 2007; Udy and Dennison, 1997; Udy et al., 1999; Walker et al., 2004). For example, while there was an increase in shoot size with nutrient $(\mathrm{N}+\mathrm{P})$ addition in Thalassia testudinum and Syringodium filiforme (Ferdie and Fourqurean, 2004), a decrease was observed in Zostera marina (Short et al., 1995). These and other similar results imply that a common response mechanism to specific stressors is lacking in seagrasses, and that adaptation and/or acclimatization to changing conditions are important in determining the level of tolerance and their reactions to specific and combinations of stressors.

Eutrophication is one of the main stressors that impacts seagrass beds and that reflects the intensity of anthropogenic activity within an area. In general, low to medium nutrient enrichment (3.5-35 $\mu \mathrm{M}$ total N) can result in increases in biomass, productivity and shoot size (Udy and Dennison, 1997), although negative effects on physiological and morphological responses to this range of concentrations have also been reported (Burkholder et al., 1992; Erftemeijer et al., 1994; Worm and Reusch, 2000). Therefore, to identify the effects that nutrient enrichment has on an individual species it is important to establish how different populations of that species respond. 
While certain nutrients can be directly toxic to seagrasses (Cabaço et al., 2008), the main pathway by which eutrophication affects seagrass meadows is via light deprivation due to increases in phytoplankton and opportunistic macroalgae (Kelaher et al., 2013). Low irradiance can negatively affect seagrasses by reducing their photosynthesis with less energy for growth and also restricting their depth distribution to shallower waters (Bryars et al., 2011). For example, Abal et al. (1994) showed that if Zostera capricorni receives, less than 100-500 $\mu \mathrm{mol}$ photons $\mathrm{m}^{-2} \mathrm{~s}^{-1}$, at the midday peak, its respiration demand exceeds the rate of carbon fixation resulting in reduced growth rates. Seagrasses have mechanisms to withstand low light conditions, such as by maintaining a large number of inactive PSII centers that act as energy quenchers of trapped light energy (Ralph, 1999), but sustained shading eventually causes the meadow's decline (Orth et al., 2006).

While the effect and relationship between nutrients and irradiance has been studied by several researchers (Leoni et al., 2008), most efforts have been concluded in situ, or in mesocosms. The correlation between these two factors under controlled laboratory conditions, in the absence of other confounding abiotic factors that could influence the results, has been scarcely studied and not at all for Cymodocea nodosa. Moreover, little is known about the interactive effects of anthropogenic stressors and natural factors (e.g. temperature, salinity, etc.) that could play an important role in these types of studies.

Metals are major sources of anthropogenic contaminants in estuaries and coastal waters in various parts of the world (Macinnis-Ng and Ralph, 2002). The kinetics of metal accumulation, and their effects on physiological and biochemical processes, is known for some seagrass species (Filho et al., 2004; Malea et al., 2013b). Results indicate that metals act on $\mathrm{CO}_{2}$ fixation, thus affecting photosynthesis and, in particular, PSII (Prasad and Strzalka, 1999). More recent studies have successfully made use of chlorophyll- $a$ fluorescence to measure the efficiency of PSII under metal exposure (Macinnis-Ng and Ralph, 2002; Ralph and Burchett, 1998), although, as yet, not on C. nodosa.

Copper $(\mathrm{Cu})$ is an essential micronutrient for photosynthetic organisms, including seagrasses, used in the synthesis of plastocyanins that play a role in transporting electrons from PSI to PSII (Macinnis-Ng and Ralph, 2002), and is actively taken up (Ambo-Rappe et al., 2011). At high concentrations, $\mathrm{Cu}$ inhibits the enzymatic activity that controls pigment biosynthesis and leads to chlorophyll degradation, depletion of iron or substitutes for magnesium in the chlorophyll atom (Malea et al., 2013a; Prasad and Strzalka, 1999), alters the permeability of thylakoid membranes and modifies the chloroplast ultrastructure (Ouzounidou, 1993). Since it inhibits electron transport at both donor and acceptor sites of PSII, exposure of shoots to $\mathrm{Cu}$ should cause a decrease in photosynthetic performance.

C. nodosa is the second most important seagrass species in the Mediterranean, in terms of ecological importance and abundance (Barbera et al., 2005; Boudouresque et al., 2009b). It is a subtidal species that can be found from shallow to very deep waters (50-60 m) in warm waters (Borum et al., 2004). In the N. Aegean it forms extensive meadows that are mostly mono-specific or mixed with Zostera noltii (Orfanidis et al., 2005). Even though it is susceptible to anthropogenic disturbances and suffers regression close to human mediated activities (Tuya et al., 2014), it is considered to be resilient to natural and anthropogenic environmental stresses in comparison to other seagrasses such as Posidonia oceanica (Marín-Guirao et al., 2013) and can display significant rates of growth that allows it to colonize bare areas within short periods of time (Cabaco et al., 2010). Its fast growth rate and ability to tolerate and quickly adapt to high levels of environmental stress make it a useful candidate species for biomonitoring programs for development bioindicators (Oliva et al., 2012; Orfanidis et al., 2010; Papathanasiou, 2013).

In this study we investigated, under controlled laboratory conditions, the effects of different combinations of three key environmental variables (light, nutrients and copper) on the photosynthetic performance of $C$. nodosa shoots collected from three populations in the $\mathrm{N}$.
Aegean Sea, Greece that are exposed to different degrees of anthropogenic disturbance. The objective was to then use the results to better understand data collected from field studies and further understand the effect of these key stressors on C. nodosa in the N. Aegean Sea.

\section{Materials and methods}

\subsection{Sample handling and study area}

Shoots were collected using SCUBA, from three meadows (Brasidas, Nea Karvali and Thasos) of known ecological status in the Kavala Gulf, N. Aegean Sea, Greece. Brasidas meadow is located in the inner part of Cape Brasidas on the Eleutheron Gulf. It is one of the least impacted areas on the mainland of the Kavala Gulf and has been included in the European Natura 2000 network (code GR1150009). Main anthropogenic activities include fishing and tourism in the wider region, as well as port activities in the nearby town of Nea Peramos. Nea Karvali is an old agricultural and fishing settlement that, since 1981, has seen increased levels of industrial development and, in particular, the establishment of a phosphorus fertilizer shoot, the Kavala city wastewater treatment facility, and a crude oil de-sulfurization complex that significantly affect the surrounding coastal area (Xeidakis et al., 2010). On the basis of the Ecological Evaluation Index (EEI) of upper infralittoral seaweed communities, Orfanidis et al. (2005a) classified Nea Karvali as of "moderate" and Brasidas as of "good" ecological status. The third meadow is located at the northern part of Thasos Island in the eastern part of Kavala Gulf, approximately $10 \mathrm{~km}$ from the mainland. The island's main income comes from tourism, while the agricultural activities do not influence significantly the coastal water quality, because of the relative high hydro-dynamism of the area. Brasidas and Thasos meadows where chosen as reference sites, while the meadow at Nea Karvali was chosen as a highly impacted one. Table 1 shows mean concentrations of key macronutrients in the water column and metal concentrations in the sediment from the studied meadows.

All shoots were collected during the summer of 2007 and 2009, at around 10:00 am, from a water depth of 2-3 $\mathrm{m}$ and transported, inside a portable cooler, to the laboratory within $30 \mathrm{~min}$. Once in the laboratory, shoots were separated and cleaned of epiphytes. Shoots with similar morphology and a $2 \mathrm{~cm}$ rhizome and a single $1 \mathrm{~cm}$ root were used. Shoots were allowed to acclimatize fully submerged in plastic aquaria tanks containing artificial seawater (ASW) without added nutrients, for $1 \mathrm{~h}$ at $21^{\circ} \mathrm{C}$ within a controlled temperature (CT) room. Münster sea salt (Meersalz) was used to produce ASW at a salinity of 35 .

Unless otherwise stated, experiments were carried out at an irradiance of $67 \mu \mathrm{mol}$ photons $\mathrm{m}^{-2} \mathrm{~s}^{-1}$ (measured at the bottom of water-filled tanks with a Li-COR Li-250 quantum sensor) on a 14:10 h (light:dark) photoperiod at $21^{\circ} \mathrm{C}$, for a period of eight days. Single shoots were placed in 11 plastic tanks containing aerated ASW of 35. All tanks were covered with watch-glasses to prevent evaporation. Each treatment had six replicates. At the start of the experiment and on alternate days, the effective quantum yield $\left(\Delta \mathrm{F} / \mathrm{Fm}^{\prime}\right)$ of the second leaf, at a position $2 \mathrm{~cm}$ above the stem, was measured using a DIVING PAM (Walz, Germany). This protocol was followed throughout as $\Delta \mathrm{F} /$ $\mathrm{Fm}^{\prime}$ is known to vary along the length of a leaf (Durako and Kunzelman, 2002). Daily measurements were avoided, since shoots, especially under high stress conditions, became very fragile, making handling difficult. The growth medium was replenished after taking measurements to prevent nutrient depletion with time.

To assess leaf elongation, a small hole was made with a needle at the base of each shoot. At the end of the experiment the distance between the hole and the basis was measured, using a ruler and the leaf elongation was calculated (Short, 1987). All experiments were conducted twice, once with shoots sampled from one of the reference sites and once from the impacted site, in order to test the importance of the shoot's acclimation history on its reaction to certain stressors. Leaf elongation wasn't measured in the P enrichment experiment. 
Table 1

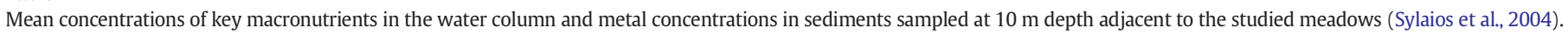

\begin{tabular}{|c|c|c|c|}
\hline Abiotic parameters & Nea Karvali (highly impacted) & Brasidas (non-impacted) & Thasos (non-impacted) \\
\hline Main human pressures & $\begin{array}{l}\text { Domestic (ca. 80,000 inhabitants), } \\
\text { industrial \& agricultural effluents }\end{array}$ & $\begin{array}{l}\text { Domestic (ca. 20,000 inhabitants) \& } \\
\text { agricultural effluents }\end{array}$ & Domestic (ca. 13,765 inhabitants) \\
\hline \multicolumn{4}{|l|}{ Seawater (surface) } \\
\hline Temperature $\left({ }^{\circ} \mathrm{C}\right)$ & 17.4 & 17.4 & 18.95 \\
\hline Salinity (PSU) & 33.7 & 33.7 & 34.1 \\
\hline $\mathrm{N}-\mathrm{NO}_{3}(\mu \mathrm{mol} / \mathrm{l})$ & 8.8 & 5.41 & 1.625 \\
\hline $\mathrm{N}-\mathrm{NO}_{2}(\mu \mathrm{mol} / \mathrm{l})$ & 0.18 & 0.15 & 0.305 \\
\hline $\mathrm{N}-\mathrm{NH}_{4}(\mu \mathrm{mol} / \mathrm{l})$ & 2.89 & 1.15 & 0.135 \\
\hline $\mathrm{P}-\mathrm{PO}_{4}(\mu \mathrm{mol} / \mathrm{l})$ & 2.57 & 1.13 & 0.98 \\
\hline \multicolumn{4}{|l|}{ Sediment } \\
\hline $\mathrm{Cu}(\mathrm{ppm})$ & 39.9 & 9.63 & NS \\
\hline $\mathrm{Ni}(\mathrm{ppm})$ & 43.8 & 11.67 & NS \\
\hline $\mathrm{Zn}(\mathrm{ppm})$ & 102.9 & 97.12 & NS \\
\hline $\mathrm{Pb}(\mathrm{ppm})$ & 31.97 & 34.51 & NS \\
\hline $\mathrm{Cd}(\mathrm{ppm})$ & 1.5 & 0.09 & NS \\
\hline $\mathrm{Cr}(\mathrm{ppm})$ & 162.3 & 32.96 & NS \\
\hline
\end{tabular}

\subsection{Experimental protocols}

To test the hypothesis that light limitation, nutrient enrichment, and copper exposure do not influence photosynthetic efficiency and leaf elongation of $C$. nodosa the following three experimental protocols were used.

\subsubsection{Effects of $N$ and P enrichment}

The effects of different combinations of $\mathrm{N}$ and $\mathrm{P}$ concentrations were tested by exposing single shoots collected from Nea Karvali and Thasos to four nutrient concentration combinations that reflected a nutrient gradient from oligotrophic (A) to eutrophic (D) conditions in the Aegean Sea. The concentrations were chosen based on the background concentrations of the study area provided in Table 1 :

$$
\begin{aligned}
& \text { A: } 0.3 \mu \mathrm{M} \mathrm{N}-\mathrm{NO}_{3-} ; 0.02 \mu \mathrm{M} \text { P-PO }{ }_{4}^{3-} \\
& \text { B: } 10 \mu \mathrm{M} \mathrm{N}-\mathrm{NO}_{3-} ; 0.5 \mu \mathrm{M} \mathrm{P}-\mathrm{PO}_{4}^{3-} \\
& \text { C: } 20 \mu \mathrm{M} \mathrm{N}-\mathrm{NO}_{3-} ; 1 \mu \mathrm{M} \mathrm{P}-\mathrm{PO}_{4}^{3-} \\
& \text { D: } 30 \mu \mathrm{M} \mathrm{N}-\mathrm{NO}_{3-} ; 2 \mu \mathrm{M} \mathrm{P}-\mathrm{PO}_{4}^{3-}
\end{aligned}
$$

\subsubsection{Effects of $\mathrm{PO}_{4}^{3-}$ enrichment under different irradiances}

The effects of $\mathrm{P}_{-} \mathrm{PO}_{4}^{3-}$ under two different irradiances (37 and $65 \mu \mathrm{mol}$ photons $\mathrm{m}^{-2} \mathrm{~s}^{-1}$ ) were tested by exposing shoots from Nea Karvali and Thasos to four concentrations $(0.02,0.5,1.0$ and $2 \mu \mathrm{M})$ while maintaining $\mathrm{N}-\mathrm{NO}_{3}$ at $30 \mu \mathrm{M}$.

\subsubsection{Effects of copper enrichment}

Shoots collected from Nea Karvali, Brasidas and Thasos meadows were exposed to 4 different $\mathrm{Cu}$ concentrations $(0,1.6,4.7$ and $7.9 \mu \mathrm{M})$ while maintaining constant concentrations of $\mathrm{N}\left(0.3 \mu \mathrm{M} \mathrm{N}-\mathrm{NO}_{3}\right)$ and $\mathrm{P}$ $\left(0.02 \mu \mathrm{M} \mathrm{P}-\mathrm{PO}_{4}\right)$, reflecting a low nutrient environment of the study area.

\subsection{Statistical analysis}

Data analysis was conducted using the R environment, provided by the $\mathrm{R}$ Foundation. Leaf elongation was analyzed using one-way ANOVA, while $\triangle \mathrm{F} / \mathrm{Fm}^{\prime}$ with repeated measurements using the "lme" function from the "nlme" package of mixed effects models. In all cases leaf elongation and $\Delta \mathrm{F} / \mathrm{Fm}^{\prime}$ ' were treated as dependent variables, treatments (N P enrichment, $\mathrm{P}$ enrichment, $\mathrm{Cu}$, light) as independent fixed variables and day and replicate as random variables. Models were accepted only when they were significantly different from the null model. One way ANOVA's between meadows were executed using the "aov" function. Statistically significant level was set at a p-value of 0.05 .

\section{Results}

\subsection{Effect of $N$ and P enrichment}

The effects of different combinations of $\mathrm{N}$ and $\mathrm{P}$ on $\Delta \mathrm{F} / \mathrm{Fm}^{\prime}$ were significant only in shoots from Thasos meadow (Table 3 ). At the end of the experiment mean value of Nea Karvali shoots in concentration A was $0.744 \pm 0.011$ SE, in B $0.755 \pm 0.013$ SE, in C $0.771 \pm 0.002$ SE and in D $0.765 \pm 0.004 \mathrm{SE}$, while of Thasos shoots in A was $0.754 \pm 0.004 \mathrm{SE}$, in B $0.755 \pm 0.013 S E$, in C $0.771 \pm 0.002$ SE and in D $0.773 \pm 0.003 S E$.

Leaf elongation showed no significant variation between the different nutrient concentrations (Table 4), even though an increasing trend was witnessed (Fig. 1). Leaves from Nea Karvali grew $1.33 \mathrm{~cm} \pm 0.4 \mathrm{SE}$ under the low nutrient concentration $\mathrm{A}, 1.79 \mathrm{~cm} \pm 0.40 \mathrm{SE}$ under $\mathrm{B}$, $1.78 \mathrm{~cm} \pm 0.44 \mathrm{SE}$ under $\mathrm{C}$ and $2.11 \mathrm{~cm} \pm 0.54 \mathrm{SE}$ under $\mathrm{D}$. Leaves from Thasos meadow grew less in the same period; under A leaf elongation was $0.84 \mathrm{~cm} \pm 0.20 \mathrm{SE}$, under $\mathrm{B} 1.18 \mathrm{~cm} \pm 0.23 \mathrm{SE}$, under $\mathrm{C}$ $0.83 \mathrm{~cm} \pm 0.18 \mathrm{SE}$ and under D $1.05 \mathrm{~cm} \pm 0.21 \mathrm{SE}$.

Shoot acclimation played a significant role to nutrient response, as shoots from Nea Karvali gave significantly higher values in their $\Delta \mathrm{F} / \mathrm{Fm}^{\prime}$ and leaf elongation to nutrient enrichment than those from Thasos (Table 5).

\subsection{Effect of $P-P_{4}^{3-}$ exposure under different light conditions}

There was no significant variation in $\Delta \mathrm{F} / \mathrm{Fm}^{\prime}$ between the low $\mathrm{P}$ $\mathrm{PO}_{4}^{3-}(0.02 \mu \mathrm{M})$ and all other treatments for shoots from both meadows or between the interaction of light and $\mathrm{P}_{-} \mathrm{PO}_{4}^{3-}$ (Table 6). At the end of the experiment mean $\Delta \mathrm{F} / \mathrm{Fm}^{\prime}$ values didn't show high variability from both meadows. Shoots from Thasos had mean $\Delta \mathrm{F} / \mathrm{Fm}^{\prime} 0.754 \pm$ $0.006 \mathrm{SE}, 0.761 \pm 0.008 \mathrm{SE}, 0.764 \pm 0.007 \mathrm{SE}$ and $0.764 \pm 0.005 \mathrm{SE}$ under $0.02,0.5,1$ and $2 \mu \mathrm{M}$ of $\mathrm{P}_{-} \mathrm{PO}_{4}^{3-}$ respectively, while shoots from Nea Karvali $0.766 \pm 0.006 S E, 0.760 \pm 0.007 S E, 0.761 \pm 0.006 S E$ and $0.755 \pm 0.009$ SE.

Table 2

Collection data of experimental materials.

\begin{tabular}{lll}
\hline Experiment & Meadow & Sampling date \\
\hline Nutrients & Nea Karvali & $17-08-2009$ \\
& Thasos & $14-07-2009$ \\
Light $+\mathrm{PO}_{4}^{3-}$ & Nea Karvali & $17-09-2009$ \\
\multirow{2}{*}{ Copper } & Thasos & $29-09-2009$ \\
& Nea Karvali & $15-06-2009$ \\
& Thasos & $29-06-2009$ \\
& Brasidas & $30-07-2007$ \\
\hline
\end{tabular}


Table 3

Mixed effect model analysis of effective quantum yield $\left(\Delta \mathrm{F} / \mathrm{Fm}^{\prime}\right)$ values of Cymodocea nodosa leaves from two meadows (Nea Karvali and Thasos) in the N. Aegean Sea, after an 8 day exposure in four nutrient concentrations ( $\mathrm{A}: 0.3 \mu \mathrm{M} \mathrm{N}-\mathrm{NO}_{3}^{-}, 0.02 \mu \mathrm{M} \mathrm{P}-\mathrm{PO}_{4}^{3-}$; B:

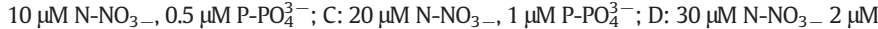
$\mathrm{P}^{-} \mathrm{PO}_{4}^{3-}$ ). Table shows comparison between treatments $\mathrm{B}, \mathrm{C}, \mathrm{D}$ and control treatment $\mathrm{A}$ (not shown).

\begin{tabular}{llrllrr}
\hline Meadow & Factor & Value & Std. error & df & t-Value & p-Value \\
\hline \multirow{2}{*}{ Nea Karvali } & Intercept & 0.746 & 0.006 & 96 & 116.385 & $<0.001$ \\
& B & 0.007 & 0.008 & 20 & 0.979 & 0.339 \\
& C & 0.004 & 0.008 & 20 & 0.529 & 0.602 \\
\multirow{5}{*}{ Thasos } & D & 0.013 & 0.007 & 20 & 1.868 & 0.077 \\
& Intercept & 0.758 & 0.004 & 95 & 186.732 & $<0.001$ \\
& B & -0.006 & 0.007 & 20 & -0.929 & 0.364 \\
& C & 0.008 & 0.005 & 20 & 1.634 & 0.118 \\
& D & 0.015 & 0.005 & 20 & 3.155 & 0.005 \\
\hline
\end{tabular}

Both shoots from Nea Karvali and Thasos experienced a significant increase of $\Delta \mathrm{F} / \mathrm{Fm}^{\prime}$ (Figs. 2 and 3), under $37 \mu \mathrm{mol}$ photons $\mathrm{m}^{2} \mathrm{~s}^{-1}$. Mean $\Delta \mathrm{F} / \mathrm{Fm}^{\prime}$ from Thasos meadow shoots increased from $0.757 \pm$ $0.002 \mathrm{SE}$ of day 0 to $0.769 \pm 0.004 \mathrm{SE}$ after 8 days under $37 \mu \mathrm{mol}$ photons $\mathrm{m}^{2} \mathrm{~s}^{-1}$, while mean $\Delta \mathrm{F} / \mathrm{Fm}^{\prime}$ decreased from $0.754 \pm$ $0.003 \mathrm{SE}$ to $0.752 \pm 0.005 \mathrm{SE}$ under $65 \mu \mathrm{mol}$ photons $\mathrm{m}^{2} \mathrm{~s}^{-1}$ during a similar period of time. Mean $\Delta \mathrm{F} / \mathrm{Fm}^{\prime}$ from Nea Karvali shoots meadow increased from $0.763 \pm 0.004 \mathrm{SE}$ to $0.769 \pm 0.002 \mathrm{SE}$ after 8 days under $37 \mu \mathrm{mol}$ photons $\mathrm{m}^{2} \mathrm{~s}^{-1}$, while $\Delta \mathrm{F} / \mathrm{Fm}^{\prime}$ decreased from $0.761 \pm 0.004 \mathrm{SE}$ to $0.752 \pm 0.006 \mathrm{SE}$ under $65 \mu \mathrm{mol}$ photons $\mathrm{m}^{2} \mathrm{~s}^{-1}$ during a similar period of time. Shoot acclimation history had no significant effect on its reaction to light treatment (Table 7).

\subsection{Copper exposure}

The $\Delta \mathrm{F} / \mathrm{Fm}^{\prime}$ of shoots from all three populations were significantly affected by concentrations greater than $1.6 \mu \mathrm{M}$ Cu (Table 8, Fig. 4). Mean $\Delta \mathrm{F} / \mathrm{Fm}^{\prime}$ from Brasidas was measured at the end of the experiment $0.763 \pm 0.006 \mathrm{SE}, 0.772 \pm 0.007 \mathrm{SE}, 0.702 \pm 0.024 \mathrm{SE}$ and $0.593 \pm$ 0.019 SE under $0,1.6,4.7$ and $7.9 \mu \mathrm{M}$ of $\mathrm{Cu}$, respectively. Similarly, mean $\Delta \mathrm{F} / \mathrm{Fm}^{\prime}$ from Thasos was measured $0.752 \pm 0.022 \mathrm{SE}, 0.758 \pm$ $0.022 \mathrm{SE}, 0.605 \pm 0.022 \mathrm{SE}$ and $0.522 \pm 0.022 \mathrm{SE}$ and from Nea Karvali was measured $0.746 \pm 0.006 \mathrm{SE}, 0.671 \pm 0.027 \mathrm{SE}, 0.518 \pm 0.051 \mathrm{SE}$ and $0.359 \pm 0.027 \mathrm{SE}$ under $0,1.6,4.7$ and $7.9 \mu \mathrm{M}$ of $\mathrm{Cu}$, respectively.

Highest $\mathrm{Cu}$ concentration decreased leaf elongation significantly only for shoots from Nea Karvali (Table 9). Fig. 5 shows the mean values of leaf elongation between all $\mathrm{Cu}$ treatments. Only the two highest $\mathrm{Cu}$ concentrations decreased leaf elongation significantly from the control (Fig. 6). Leaves grew $2.93 \mathrm{~cm} \pm 0.61 \mathrm{SE}$ under the control treatment, $1.89 \mathrm{~cm} \pm 0.47 \mathrm{SE}$ under $1.6 \mu \mathrm{M} \mathrm{Cu}, 1.15 \mathrm{~cm} \pm 0.35 \mathrm{SE}$ under $4.7 \mu \mathrm{M}$ $\mathrm{Cu}$ and $0.98 \mathrm{~cm} \pm 0.15 \mathrm{SE}$ under $7.9 \mu \mathrm{M} \mathrm{Cu}$.

There was no significant effect of $\mathrm{Cu}$ on the elongation of leaves from Thasos (Table 9), even though a negative trend could be seen (Fig. 5). Leaves grew $1.84 \mathrm{~cm} \pm 0.27 \mathrm{SE}$ under control treatment, $1.26 \mathrm{~cm} \pm$ $0.38 \mathrm{SE}$ under $1.6 \mu \mathrm{M} \mathrm{Cu}, 1.08 \mathrm{~cm} \pm 0.33 \mathrm{SE}$ under $4.7 \mu \mathrm{M} \mathrm{Cu}$ and $0.72 \mathrm{~cm} \pm 0.15 \mathrm{SE}$ under $7.9 \mu \mathrm{M} \mathrm{Cu}$.

As shown in Table 10, shoots from Thasos and Brasidas meadows had a similar reaction to $\mathrm{Cu}$ enrichment that was significantly different from that from the ones from Nea Karvali $(\mathrm{p}<0.05)$. Leaf elongation was also significantly different between Nea Karvali and Thasos meadows.

\section{Table 4}

One way ANOVA of Cymodocea nodosa leaf elongation from two meadows (Nea Karvali and Thasos) in the N. Aegean Sea, after an 8 day exposure to four nutrient concentrations. For more information see Table 3.

\begin{tabular}{lll}
\hline Meadow & F & p-Value \\
\hline Nea Karvali & 0.478 & 0.700 \\
Thasos & 0.641 & 0.593 \\
\hline
\end{tabular}

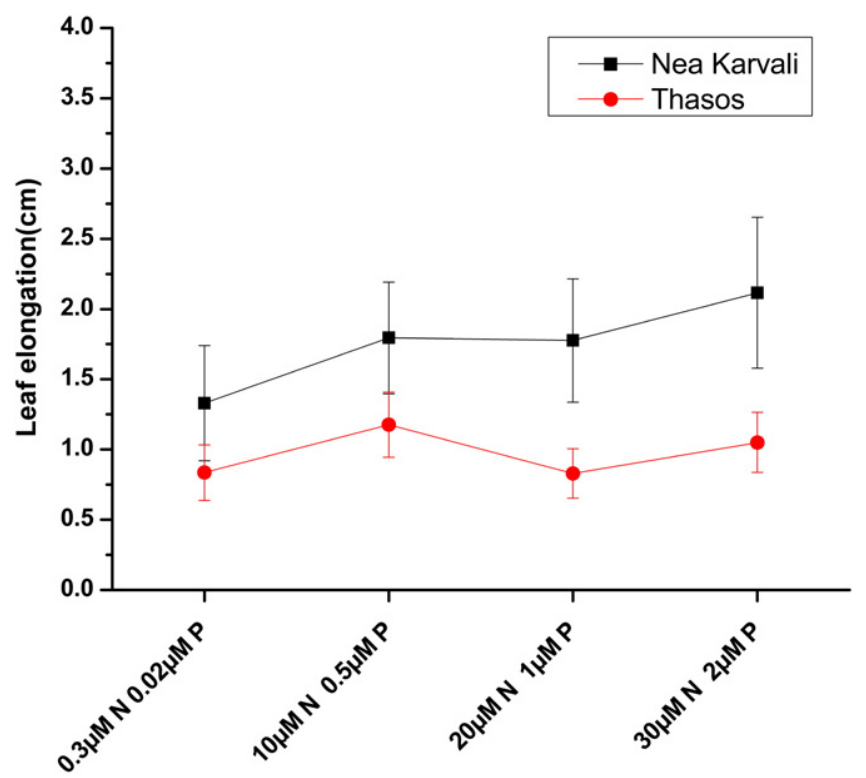

Fig. 1. Cymodocea nodosa mean leaf elongation values ( \pm standard error, $n=6$ ) after 8 days exposure to four nutrient concentrations ( $\mathrm{A}: 0.3 \mu \mathrm{M} \mathrm{N}-\mathrm{NO}_{3-}, 0.02 \mu \mathrm{M} \mathrm{P}_{-} \mathrm{PO}_{4}^{3-}$; B: $10 \mu \mathrm{M} N-\mathrm{NO}_{3-}, 0.5 \mu \mathrm{M}$ P-PO ${ }_{4}^{3-}$; C: $20 \mu \mathrm{M} \mathrm{N}-\mathrm{NO}_{3-}, 1 \mu \mathrm{M}$ P-PO ${ }_{4}^{3-}$; D: $30 \mu \mathrm{M} \mathrm{N}-\mathrm{NO}_{3-}, 2 \mu \mathrm{M}$ $\mathrm{P}_{-} \mathrm{PO}_{4}^{3-}$ ) sampled from two meadows (Nea Karvali and Thasos) in the N. Aegean Sea.

\section{Discussion}

\subsection{Nutrient exposure}

In this study, the combination of nutrients $(\mathrm{N}+\mathrm{P})$ significantly increased shoot photosynthetic performance $\left(\Delta \mathrm{F} / \mathrm{Fm}^{\prime}\right)$ in shoots from the oligotrophic site of Thasos but only under high concentrations (Tables 2,3). The late summer period, when these experiments were conducted, is characterized by relatively low nutrient availability due to spring-summer uptake by phytoplankton, fast growing epiphytes and opportunistic macroalgae (Orfanidis and Panayotidis, 2005; Sylaios et al., 2005), and coincides with the end of the optimal growing season for C. nodosa (Leoni et al., 2006). These conditions can also be seen in the significantly lower nitrogen and phosphorus content in shoot tissues measured during the summer period $1.867 \% \mathrm{DW} \pm$ $0.545 \mathrm{SE}$ and $0.192 \% \mathrm{DW} \pm 0.045 \mathrm{SE}$, respectively) (Papathanasiou, 2013). In contrast, nutrient enrichment had no effect on $\Delta \mathrm{F} / \mathrm{Fm}^{\prime}$ of shoots from the impacted site of Nea Karvali where nutrient concentrations in the water column can be from 1.5 to 2.5 times higher (Sylaios et al., 2005) and therefore sufficient to be stored in shoot tissue and to support photosynthesis for 8 days. Shoots from Nea Karvali have been found to store 1.84 times more $\mathrm{N}$ and 1.61 more $\mathrm{P}$ in their leaves than shoots from Brasidas (Papathanasiou, 2013). A similar response has been reported for several seagrass species (Agawin et al., 1996; Lee et al., 1999) including P. oceanica, that had twice the photosynthetic capacity at a slightly eutrophic site compared to shoots from an oligotrophic one (Agawin et al., 1996; Lee and Dunton, 1999).

The decline in seagrass meadows under nutrient enrichment is most commonly linked to indirect ecological processes, mainly through the

Table 5

Mixed effect model analysis of Cymodocea nodosa leaf elongation and effective quantum yield $\left(\Delta \mathrm{F} / \mathrm{Fm}^{\prime}\right)$ after an 8 day exposure to four nutrient concentrations between two meadows, Nea Karvali and Thasos in the N. Aegean Sea. For more information see Table 3.

\begin{tabular}{llrlrrr}
\hline Parameter & Factor & Value & Std. error & df & t-Value & p-Value \\
\hline \multirow{2}{*}{$\mathrm{F} / \mathrm{Fm}^{\prime}$} & Intercept & 0.753 & 0.002 & 192 & 308.407 & $<0.001$ \\
& Thasos & 0.010 & 0.003 & 46 & 2.775 & 0.008 \\
\multirow{2}{*}{ Leaf elongation } & Intercept & 1.755 & 0.169 & 137 & 10.36 & $<0.001$ \\
& Thasos & -0.785 & 0.22 & 137 & -3.564 & 0.001 \\
\hline
\end{tabular}


Table 6

Mixed effect model analysis of effective quantum yield $\left(\Delta \mathrm{F} / \mathrm{Fm}^{\prime}\right)$ values of Cymodocea nodosa leaves from two meadows (Thasos and Nea Karvali) in the N. Aegean Sea, after an 8 day exposure in four $\mathrm{P}_{-} \mathrm{PO}_{4}^{3-}$ concentrations (A: 0.02; B: $0.5 ; \mathrm{C}: 1 ; \mathrm{D}: 2 \mu \mathrm{M}$ ), under two different light conditions ( 37 and $65 \mu \mathrm{mol}$ photons $\mathrm{m}^{2} \mathrm{~s}^{-1}$ ). For more information see Table 3.

\begin{tabular}{llcllcc}
\hline Meadow & Factor & Value & Std. Error & df & t-Value & p-Value \\
\hline Thasos & Intercept & 0.76 & 0.004 & 191 & 200.486 & $<0.001$ \\
& Low light & 0.013 & 0.004 & 191 & 2.91 & 0.004 \\
& B & -0.002 & 0.006 & 41 & -0.266 & 0.792 \\
& C & 0.001 & 0.006 & 41 & 0.245 & 0.808 \\
& D & -0.006 & 0.006 & 41 & -1.086 & 0.284 \\
& B: low light & 0.003 & 0.007 & 41 & 0.426 & 0.672 \\
& C: low light & 0.005 & 0.007 & 41 & 0.782 & 0.439 \\
& D: low light & 0.009 & 0.007 & 41 & 1.25 & 0.218 \\
& Intercept & 0.747 & 0.007 & 192 & 101.957 & $<0.001$ \\
& Low light & 0.024 & 0.008 & 40 & 3.074 & 0.004 \\
& B & 0.009 & 0.009 & 40 & 0.986 & 0.33 \\
& C & -0.001 & 0.01 & 40 & -0.06 & 0.952 \\
& D & 0.001 & 0.01 & 40 & 0.125 & 0.901 \\
& B: low light & -0.006 & 0.01 & 40 & -0.556 & 0.581 \\
& C: low light & 0.001 & 0.011 & 40 & 0.071 & 0.944 \\
& D: low light & 0 & 0.011 & 40 & 0.027 & 0.978 \\
\hline
\end{tabular}

stimulation of algal biomass that causes light limitation (Tuya et al., 2013), although there is some evidence linking such declines directly to physiological mechanisms, typically shoot die-off due to internal carbon limitation (Touchette and Burkholder, 2000). While this relationship has not been tested for all seagrass species, of those tested, most display limited or negligible nutrient feedback inhibition and continue to take up nutrients at high rates for as long as they are available in the environment (Burkholder et al., 2007; Mvungi and Mamboya, 2012). The evolution of seagrasses under oligotrophic conditions has led to the development of a sustained nutrient uptake and assimilation processes to take advantage of temporary enrichment that would eventually cease. Since nitrate assimilation and reduction is energetically costly, continuous exposure to high $\mathrm{N}$ concentrations would eventually lead to significant declines in shoot growth, by consuming carbohydrate reserves for synthesizing amino acids and resulting in internal carbon limitation (Leoni et al., 2008). This mechanism was responsible for the 75-95\% shoot die-off in Z. marina following exposure to low nitrate enrichment (3.5 and $7 \mu \mathrm{M}$ ) for 7 weeks (Burkholder et al., 1992). The short experimental period ( 8 days) used in our study was not sufficient to observe this phenomenon in C. nodosa, but it was established that a short period of nutrient enrichment had no generic effect on the photosynthetic activity of the shoots. Longer exposure to high nutrient concentrations would eventually lead to the meadow degradation, but the main pathway would be through the increased biomass of algae and epiphytes, rather than toxic effect on the shoot (Tuya et al., 2013).

Leaf elongation showed no significant response to nutrient concentrations (Table 4), even though an increasing trend can be seen in Fig. 1. Typically, seagrasses growing under intermediate concentrations of nutrients, and non-limiting light conditions, increase their rates of uptake and assimilation. The excess nutrients are used in carbon fixation through increased photosynthetic activity, to produce more biomass (Lee et al., 2007). However, a lack of a growth response to nutrient enrichment has been documented for other species (Kenworthy and Fonseca, 1992; Ramirez Garcia et al., 2002; Udy and Dennison, 1997), suggesting that other mechanisms are influential such as seasonality or temperature. C. nodosa displays a high degree of phenotypic plasticity and seasonality has been identified as a key driver affecting its phenology and behavior (Reyes et al., 1995). In these experiments temperature was maintained at $21^{\circ} \mathrm{C}$, reflecting the environmental conditions of late spring-early summer but this temperature is close to the lower end of the optimum for the growth of $C$. nodosa in the N. Aegean Sea (unpublished data). Genetic adaptation may also play an important role, as the three populations have been identified to be genetically different ecotypes (Orfanidis et al., 2014).

\subsection{Effect of $\mathrm{PO}_{4}^{3-}$ exposure under different light conditions}

Phosphorus and light were chosen for these experiments since they have been identified as key abiotic factors that are linked to the anthropogenic stress gradient in the region of N. Aegean Sea (Orfanidis et al., 2010). Despite this, increasing concentrations of $\mathrm{PO}_{4}^{3-}$ had no significant effect on $\Delta \mathrm{F} / \mathrm{Fm}^{\prime}$, even though this set of experiments was run in mid to late September (Table 3) when nutrients in the water column are relatively low. Light, however, did significantly affect $\Delta \mathrm{F} / \mathrm{Fm}^{\prime}$ (Table 6). In both experiments conducted, low irradiance ( $37 \mu \mathrm{mol}$ photons $\mathrm{m}^{-2} \mathrm{~s}^{-1}$ ) resulted in higher $\Delta \mathrm{F} / \mathrm{Fm}^{\prime}$ than higher values ( $65 \mu \mathrm{mol}$ photons $\mathrm{m}^{-2} \mathrm{~s}^{-1}$ ), while the source meadow of the material had no significant influence on their response (Table 7). These findings are consistent with studies of other seagrass species where high light (100-1000 $\mu \mathrm{mol}$ photons $\mathrm{m}^{-2} \mathrm{~s}^{-1}$ ) caused significant declines in photosynthetic activity, including $\Delta \mathrm{F} / \mathrm{Fm}^{\prime}$, as well as shoot size and chlorophyll content (Abal et al., 1994; Beer and Waisel, 1982; Bite et al., 2007; Dennison, 1987; Kraemer and Hanisak, 2000; Lee and Dunton, 1997; Longstaff et al., 1999; Masini et al., 1995; Ralph, 1999; Ralph and Burchett, 1995).

The increased $\Delta \mathrm{F} / \mathrm{Fm}^{\prime}$ values in low light treatments reflect the shoots' effort to increase their photosynthetic efficiency, in order to capture more photons and sustain growth. For this reason, the minimum quantum requirements for photosynthesis $\left(1 / \Phi_{\max }\right)$ are reduced to approach the theoretical minimum of 8 photons (Govindjee, 1999) and leaf absorptance is enhanced (Ralph et al., 2007), usually by increasing the chlorophyll content of shoots (Longstaff and Dennison, 1999). Other reported photo-adaptative responses include increased maximum effective yield (Fv/Fm), photosynthetic efficiency $(a)$, reduced maximum electron transport rate $\left(\mathrm{rETR}_{\max }\right)$ and a reduction in the saturating irradiance $\left(E_{k}\right)$, data that can be collected from rapid light curves (RLC) (Ralph and Gademann, 2005). Increases in $\Delta \mathrm{F} / \mathrm{Fm}^{\prime}$ were noted within the first two days of the experiments and were greater in shoots from Thasos, probably due to the higher irradiances these shoots receive in the field. After 8 days of exposure mean $\Delta \mathrm{F} / \mathrm{Fm}^{\prime}$ values were the same for both light conditions, regardless of the source of material, a result that highlights the significance of light as an ecological quality factor, as well as $C$. nodosa's ability to acclimatize to prevailing conditions.

\subsection{Copper exposure}

The $\Delta \mathrm{F} / \mathrm{Fm}^{\prime}$ of shoots from all three studied meadows were negatively affected by exposure to copper. While the lowest copper concentration $(1.6 \mu \mathrm{M})$ had no significant effect, concentrations of $4.7 \mu \mathrm{M}$ and $7.9 \mu \mathrm{M}$ caused significant declines (Table 8 ). These negative effects were observed 2 days earlier in shoots from Nea Karvali than from Thasos and Brasidas (Fig. 4). The decreases in variable fluorescence $(\mathrm{Ft})$ and maximum fluorescence $\left(\mathrm{Fm}^{\prime}\right)$, are indicative of a reduction in the available reaction center pools of PSII (Macinnis-Ng and Ralph, 2004a). Copper is a micronutrient required for plastocyanin production, a protein utilized in electron transport from cytochrome $f$ to PSII, but under high $\mathrm{Cu}$ concentrations it impedes electron transport between PSI and PSII (Govindjee, 1995). Concurrently, Cu causes chlorosis and alters plasma-membrane permeability that eventually leads to ion leakage (Ouzounidou et al., 1992). More specifically, Cu attacks sulphydryl groups of membranes, thus damaging permeable layers and allowing ion diffusion into the chloroplast leading to its degradation (Ouzounidou, 1994).

Significant inhibition of leaf elongation occurred in shoots from Nea Karvali, but not from Thasos, under the two highest $\mathrm{Cu}$ concentrations (Fig. 5). The significance of the previous to a stress incident shoot acclimation history as well as the environmental conditions may hold a significant role in the meadows' reaction and their ability to survive. Ambo-Rappe et al. (2011) commented on the unpredictable nature of metal exposure, presenting conflicting data on the effects of metal exposure on the morphology of Halophila ovalis. Increasing metal concentrations resulted in reduced morphological traits in laboratory 


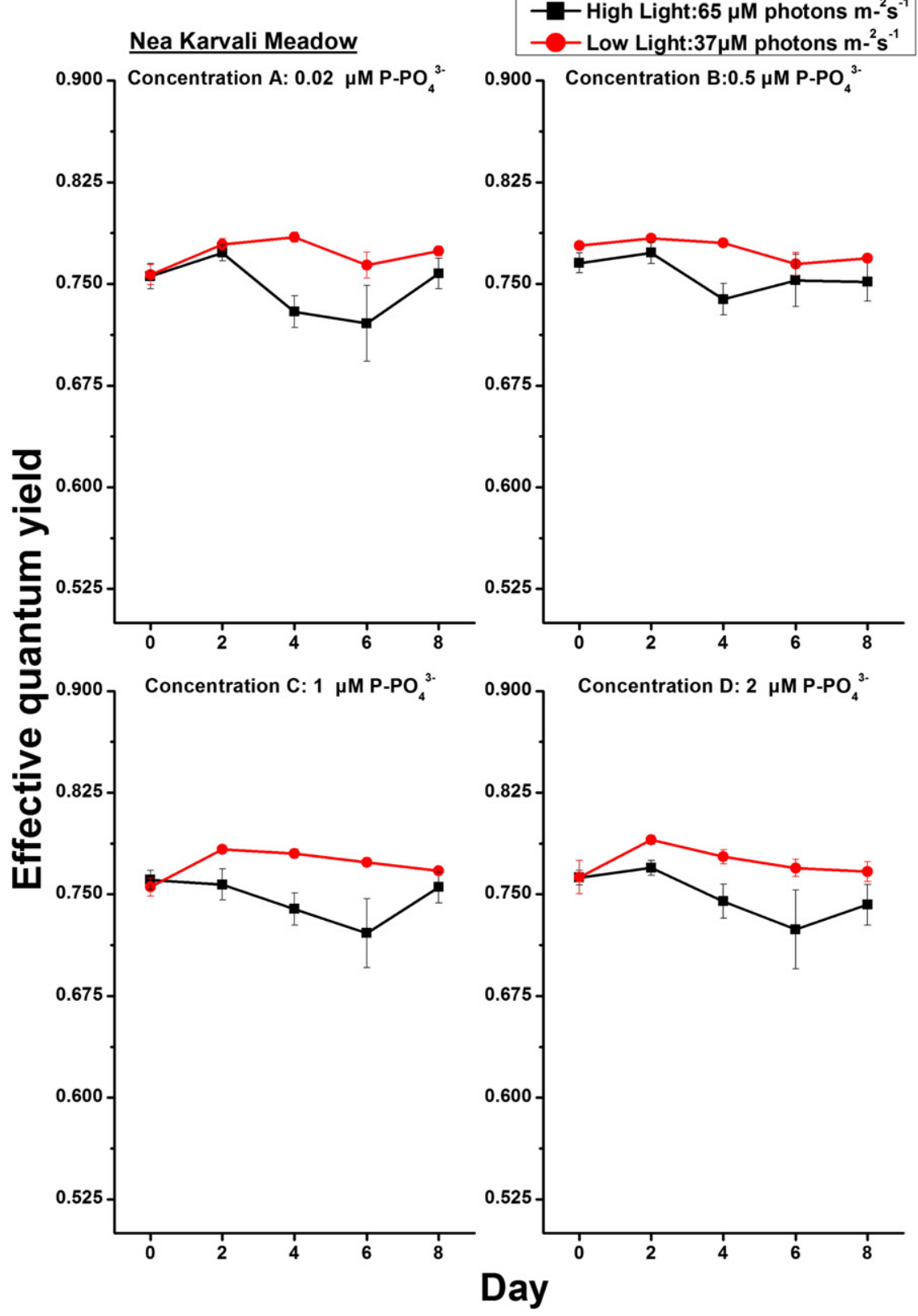

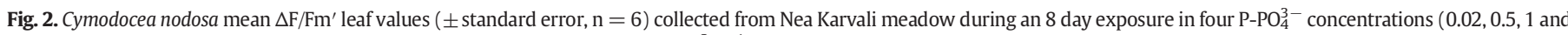
$2 \mu \mathrm{M} ; \mathrm{N} 30 \mu \mathrm{M}$ ), under two different light conditions (37 and $65 \mu \mathrm{mol}$ photons $\mathrm{m}^{2} \mathrm{~s}^{-1}$ ).

experiments, while the opposite had been observed in the field. One explanation is that concentrations used in laboratory experiments were significantly higher than those usually met in the field, in order to yield a response. Also metal adsorption and uptake are affected by bioavailability which is influenced by various environmental and biological factors such as $\mathrm{pH}$, sediment particle size, temperature, salinity, seasonality species-specific effects, type and age of tissue (Ralph et al., 2006).

Leaf senescence due to increased copper concentration has been reported for many seagrass species (Ambo-Rappe et al., 2011; Malea et al., 1995) and was also observed in this study, especially in shoots from Nea Karvali. This phenomenon is associated with the stimulation of phytochrome activity, which leads to increased abscisic acid and ethylene production, that in turn signals the leaf abscission and loosening of cell walls (Malea and Kevrekidis, 2013; Malea et al., 1995).

Negative effect of metal concentrations on $\Delta \mathrm{F} / \mathrm{Fm}^{\prime}$ has been reported for other seagrass species too (Macinnis-Ng and Ralph, 2002, 2004a; Ralph and Burchett, 1998). Like most shoots, they can cope with metals through three pathways. They can isolate the metals to a neutral function, sequester the toxic particle, or metabolize it by biotransformation enzymes, increasing their water solubility (Pergent-Martini and Pergent, 2000). Considering that $\mathrm{Cu}$ has a number of impact sites on the shoot, it isn't always easy to predict the endpoint of the toxic event and the ability to withstand metal stress is linked to an individual shoot's or population's ability to undergo physiological modifications, or evolve mechanisms of resistance (Klerks and Weis, 1987).

Shoots from the less impacted meadows demonstrated a higher tolerance to copper, as they were affected less by a medium copper concentration $(4.7 \mu \mathrm{M})$ and even under a higher concentration $(7.9 \mu \mathrm{M})$ still maintained an increased photosynthetic efficiency in comparison to shoots from Nea Karvali meadow (Fig. 4). Jepson and Sherratt (1996) suggested that assessment of ecotoxicological risks can be highly site specific, while Foy et al. (1978) discussed the evolution of metal tolerant ecotypes within shoot species. Macinnis-Ng and Ralph (2004b) studied metal exposure on $Z$. capricorni from three isolated populations. 


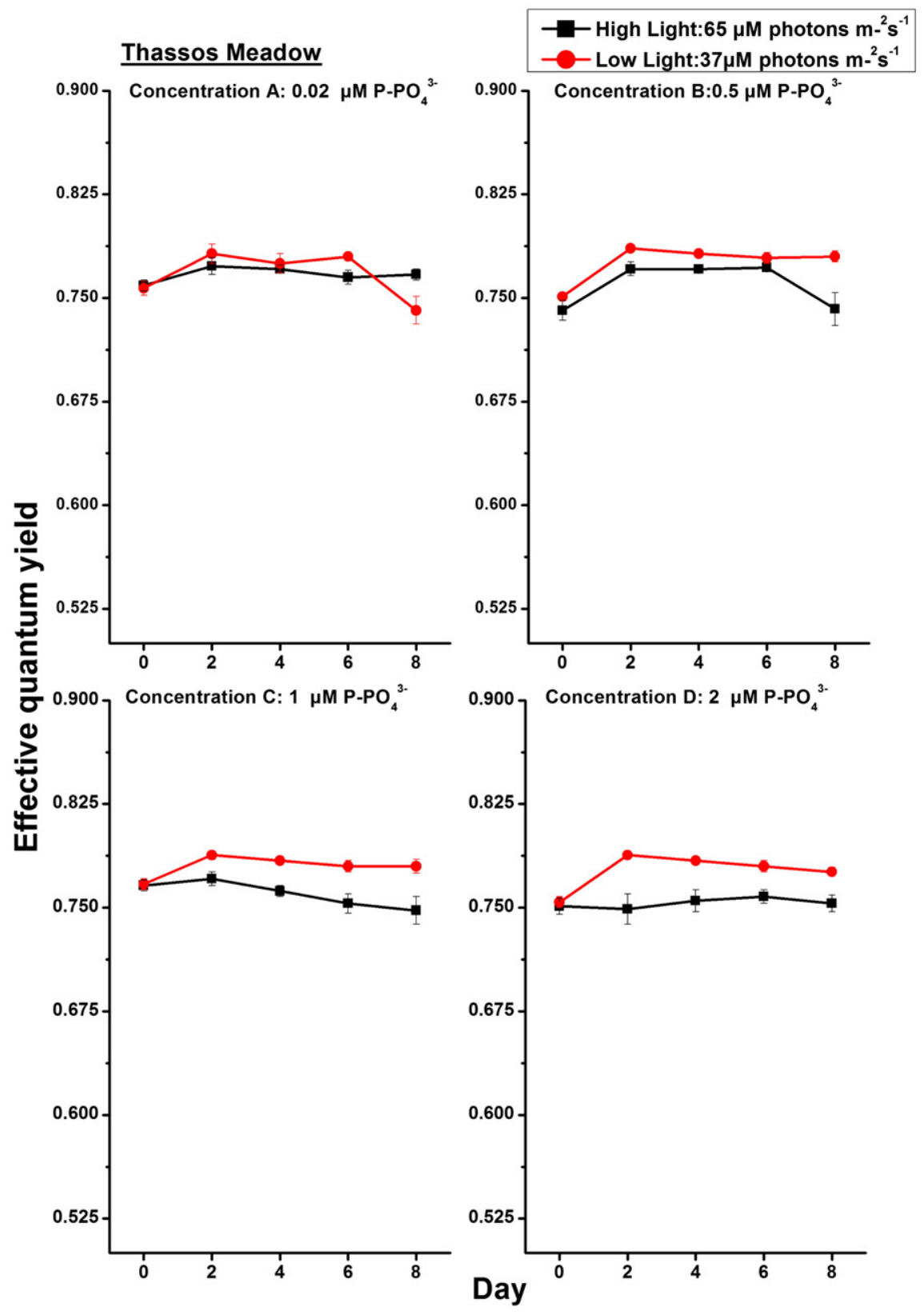

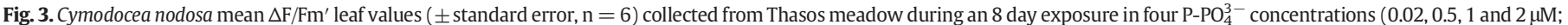
$\mathrm{N} 30 \mu \mathrm{M}$ ), under two different light conditions ( 37 and $65 \mu \mathrm{mol}$ photons $\mathrm{m}^{2} \mathrm{~s}^{-1}$ ).

Even though they hypothesized that shoots previously exposed to metals would be more resistant than naïve ones, they found a significant decrease in chlorophyll- $a$ fluorescence with additions of 500 and $1000 \mu \mathrm{g} \mathrm{l} \mathrm{l}^{-1}$ of $\mathrm{Cu}$ only in shoots from a polluted site, while the mechanisms responsible couldn't be identified.

An explanation could be based on differential copper adsorption and uptake, a surface-area dependent process (Malea et al., 1995), that

\section{Table 7}

One way ANOVA of Cymodocea nodosa leaf elongation from two meadows (Nea Karvali and Thasos) in the N. Aegean Sea, after an 8 day exposure to four $\mathrm{P}_{-} \mathrm{PO}_{4}^{3-}$ concentrations and two light conditions. For more information see Tables 3, 6.

\begin{tabular}{lrlllr}
\hline Factor & Value & Std. error & df & t-Value & p-Value \\
\hline Intercept & 0.762 & 0.004 & 384 & 184.808 & $<0.001$ \\
Thasos & -0.007 & 0.006 & 91 & -1.125 & 0.264
\end{tabular}

Table 8

Mixed effect model analysis of effective quantum yield values of Cymodocea nodosa leaves from three meadows (Brasidas, Thasos and Nea Karvali) in the N. Aegean Sea, after an 8 day exposure in four $\mathrm{Cu}$ concentrations (A: 0, B: 1.6, C: 4.7 and D: $7.9 \mu \mathrm{M}$ ), under $0.3 \mu \mathrm{M}$ $\mathrm{N}-\mathrm{NO}_{3}$ - and $0.02 \mu \mathrm{M} \mathrm{P}_{-} \mathrm{PO}_{4}^{3-}$. For more information see Table 3.

\begin{tabular}{llrllrr}
\hline Meadow & Concentration & \multicolumn{1}{c}{ Value } & Std. error & df & t-Value & p-Value \\
\hline Brasidas & Intercept & 0.758 & 0.005 & 96 & 167.306 & $<0.001$ \\
& B & 0.013 & 0.006 & 20 & 2.057 & 0.053 \\
& C & -0.018 & 0.006 & 20 & -2.849 & 0.010 \\
\multirow{5}{*}{ Nea Karvali } & D & -0.039 & 0.006 & 20 & -6.047 & $<0.001$ \\
& Intercept & 0.746 & 0.011 & 93 & 70.192 & $<0.001$ \\
& B & 0.011 & 0.015 & 20 & 0.750 & 0.462 \\
& C & -0.045 & 0.015 & 20 & -2.963 & 0.008 \\
& D & -0.077 & 0.015 & 20 & -5.115 & $<0.001$ \\
& Intercept & 0.764 & 0.004 & 96 & 198.661 & $<0.001$ \\
& B & 0.004 & 0.005 & 20 & 0.761 & 0.456 \\
& C & -0.061 & 0.012 & 20 & -5.193 & $<0.001$ \\
& D & -0.114 & 0.028 & 20 & -4.047 & 0.001 \\
\hline
\end{tabular}



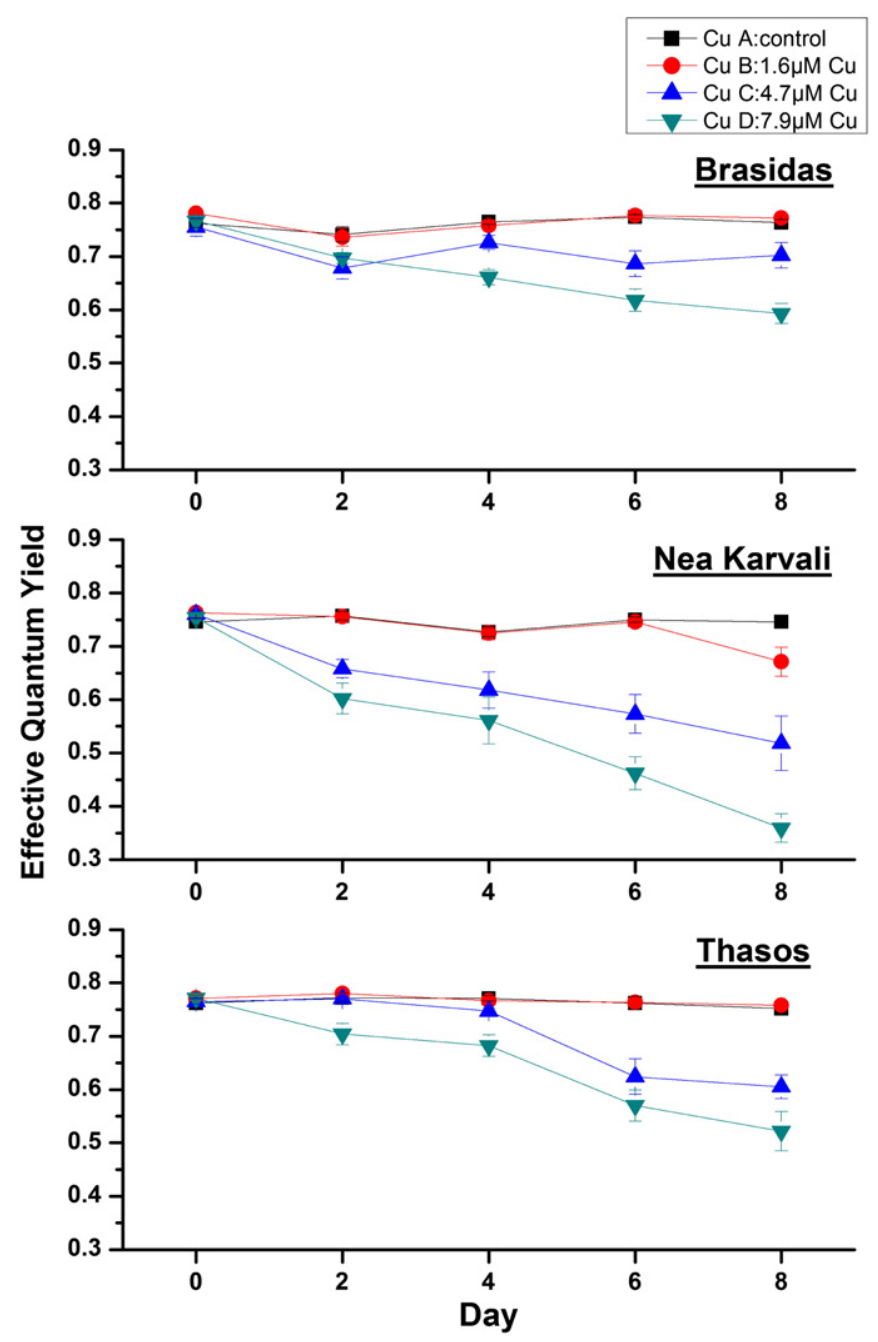

Fig. 4. Mean values of $\Delta \mathrm{F} / \mathrm{Fm}^{\prime}$ ( \pm standard error, $\mathrm{n}=6$ ) of Cymodocea nodosa leaves from three meadows (Brasidas, Thasos and Nea Karvali) in N. Aegean Sea after an 8 day exposure to four Cu concentrations: A: 0, B: 1.6, C: 4.7 and D: $7.9 \mu \mathrm{M}$, with the addition of $0.3 \mu \mathrm{M} \mathrm{N}-\mathrm{NO}_{3-}, 0.02 \mu \mathrm{M}-\mathrm{PO}_{4}^{3-}$.

enables longer and wider leaves from Nea Karvali to remove more $\mathrm{Cu}$ than leaves from pristine sites, since they employ more binding sites. At the same time, $\mathrm{Cu}$ concentration in Nea Karvali meadow measured in the sediment (39.9 ppm) were found to be significantly higher than those measured in Brasidas meadow (9.63 ppm) (Sylaios et al., 2004), leading to a greater internal concentration within shoots from the first meadow, that with the addition of more copper led to a faster negative physiological response. Even under these extreme conditions shoots from the undisturbed meadows maintained higher $\Delta \mathrm{F} / \mathrm{Fm}^{\prime}$ values,

Table 9

One way ANOVA of Cymodocea nodosa leaf elongation from two meadows (Nea Karvali and Thasos) in the N. Aegean Sea, after an 8 day exposure to four $\mathrm{Cu}$ concentrations. Table shows comparisons between treatments B, C, D and control treatment A. For more information see Tables 3, 8 .

\begin{tabular}{llrlrr}
\hline Meadow & Factor & Estimate & Std. error & t Value & p-Value \\
\hline Nea Karvali & Intercept & 2.926 & 0.443 & 6.606 & $<0.001$ \\
& B & -1.039 & 0.599 & -1.736 & 0.086 \\
& C & -1.776 & 0.619 & -2.871 & 0.005 \\
\multirow{2}{*}{ Thasos } & D & -1.950 & 0.611 & -3.190 & 0.002 \\
& Intercept & 1.184 & 0.256 & 4.634 & $<0.001$ \\
& B & 0.080 & 0.392 & 0.204 & 0.839 \\
& C & -0.106 & 0.392 & -0.269 & 0.789 \\
& D & -0.463 & 0.361 & -1.280 & 0.205 \\
\hline
\end{tabular}

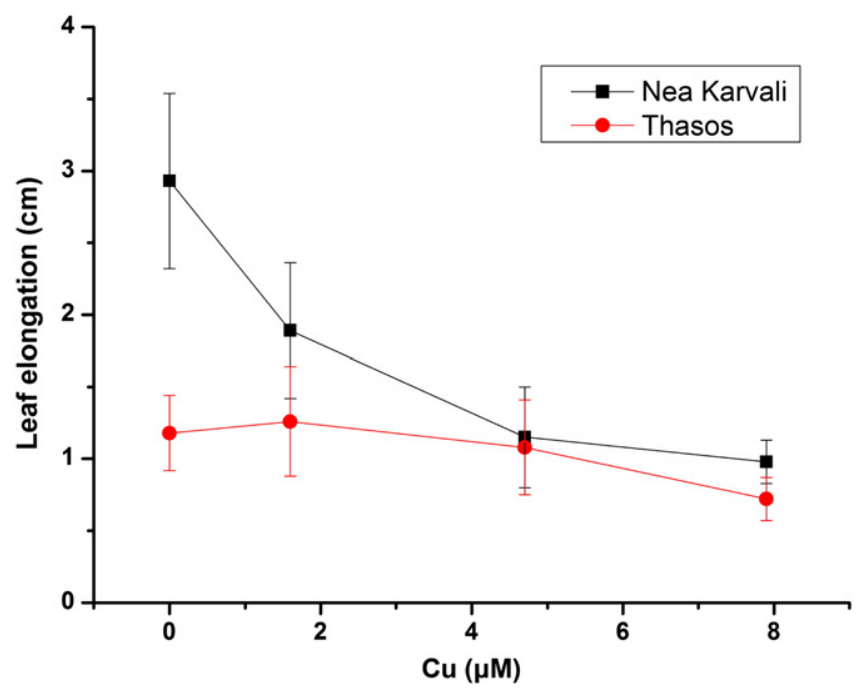

Fig. 5. Cymodocea nodosa mean leaf elongation values ( \pm standard error, $n=6$ ) from two meadows (Nea Karvali and Thasos) in N. Aegean Sea, after an 8 day exposure to $4 \mathrm{Cu}$ concentrations (A: 0, B: 1.6, C: 4.7 and D: $7.9 \mu \mathrm{M}$ ) and $0.3 \mu \mathrm{M} \mathrm{N}-\mathrm{NO}_{3-} 0.02 \mu \mathrm{M} \mathrm{P}^{-} \mathrm{PO}_{4}$.

although there was a greater initial reduction until the end of the experiment and in contrast to shoots from Nea Karvali, senescence was limited. Further studies of the physiochemical parameters, measuring internal versus extra-cellular Cu concentrations, with multi-stressor experiments (such as nutrients-light-copper) as well as the genetics of the populations involved could help determine the influence of genetic variation in Cu resistance.

\section{Conclusions}

The results of this study clearly indicate the need to explore evolutionary adaptation and phenotypic plasticity before appropriate management decisions made to protect $C$. nodosa from anthropogenic stress in order to avoid misinterpretation of field results and to focus efforts on the most crucial and sensitive factors, such as light availability. While high nitrate and phosphate concentrations improved the photosynthesis of only nutrient limited shoots from pristine sites, light proved
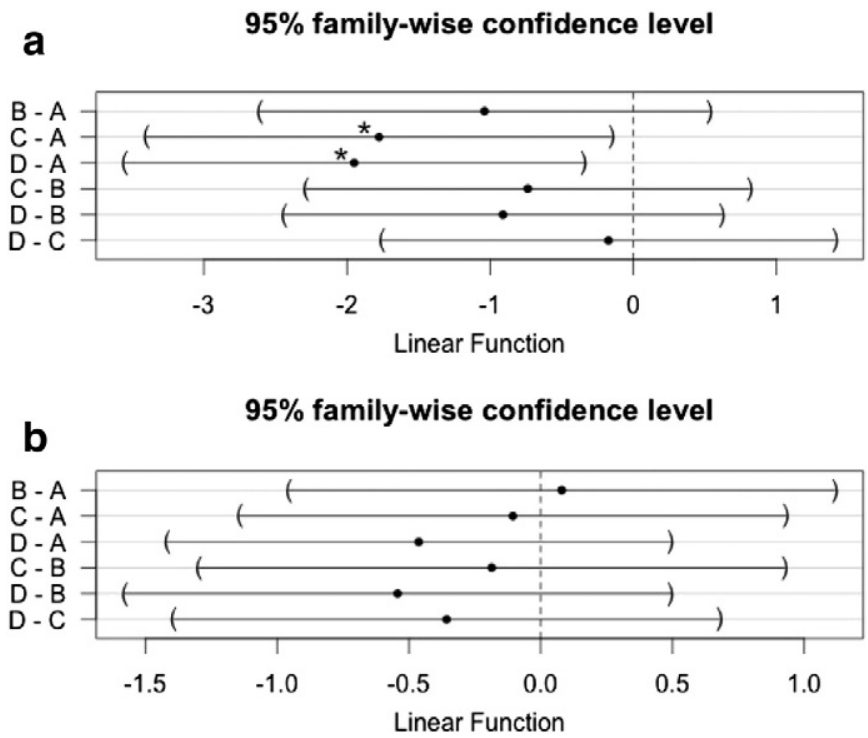

Fig. 6. Post hoc pairwise comparisons of Cymodocea nodosa leaf elongation from two meadows in the N. Aegean sea (a-Nea Karvali, b-Thasos) after an 8 day exposure to four copper concentrations (A: 0, B: 1.6, C: 4.7 and D: $7.9 \mu \mathrm{M}$ ) for shoots with $95 \%$ confidence intervals using the Tukey test. Denotes statistical significant difference. 
Table 10

Mixed effect model analysis of Cymodocea nodosa a) $\Delta \mathrm{F} / \mathrm{Fm}^{\prime}$ and b) leaf elongation response to 4 levels of copper concentration exposure for 8 days, on samples from three meadows (Brasidas, Nea Karvali and Thasos) in N. Aegean Sea. Table shows comparisons between Brasidas meadow and the two others. For more information see Tables 3, 8.

\begin{tabular}{|c|c|c|c|c|c|}
\hline a) $\Delta \mathrm{F} / \mathrm{Fm}^{\prime}$ & Value & Std. error & df & t-Value & p-Value \\
\hline Intercept & 0.767 & 0.004 & 351 & 209.854 & $<0.001$ \\
\hline Nea Karvali & -0.029 & 0.005 & 351 & -6.166 & $<0.001$ \\
\hline Thasos & 0.006 & 0.004 & 351 & 1.532 & 0.126 \\
\hline \multicolumn{2}{|c|}{ b) Leaf elongation } & $\mathrm{F}$ & \multicolumn{2}{|r|}{ df } & p-Value \\
\hline \multicolumn{2}{|l|}{ Nea Karvali } & 3.926 & \multicolumn{2}{|r|}{3} & 0.016 \\
\hline \multicolumn{2}{|l|}{ Thasos } & 1.233 & \multicolumn{2}{|r|}{3} & 0.315 \\
\hline
\end{tabular}

to be the most important factor affecting photosynthesis. In particular, low irradiance caused an increase of $\Delta \mathrm{F} / \mathrm{Fm}^{\prime}$ independent of the material's source. Copper proved to be a toxic metal, especially for highly stressed meadow, but only under high concentrations that are very rarely met in the environment and can have an effect only after chronic exposure. Therefore, high PAM fluorescence values measured in anthropogenic stressed environments of N. Aegean Sea and elsewhere seem to be mainly linked to water turbidity caused indirectly by different human activities and validate this methodology as promising in water management. [ST]

\section{References}

Abal, E.G., Loneragan, N., Bowen, P., Perry, C.J., Udy, J.W., Dennison, W.C., 1994. Physiological and morphological responses of the seagrass Zostera capricorni Aschers., to light intensity. J. Exp. Mar. Biol. Ecol. 178 (1), 113-129.

Agawin, N., Duarte, C., Fortes, M., 1996. Nutrient limitation of Philippine seagrasses (Cape Bolinao, NW Philippines): in situ experimental evidence. Mar. Ecol. Prog. Ser. 138, 233-243.

Ambo-Rappe, R., Lajus, D.L., Schreider, M.J., 2011. Heavy metal impact on growth and leaf asymmetry of seagrass, Halophila ovalis. J. Environ. Chem. Ecotoxicol. 3 (6), 149-159.

Barbera, C., Tuya, F., Boyra, A., Sanchez-Jerez, P., Blanch, I., Haroun, R.J., 2005. Spatial variation in the structural parameters of Cymodocea nodosa seagrass meadows in the Canary Islands: a multiscaled approach. Bot. Mar. 48, 122-126.

Beer, S., Waisel, Y., 1982. Effects of light and pressure on photosynthesis in two seagrasses. Aquat. Bot. 13, 331-337.

Bite, J.S., Campbell, S.J., McKenzie, L.J., Coles, R.G., 2007. Chlorophyll fluorescence measures of seagrasses Halophila ovalis and Zostera capricorni reveal differences in response to experimental shading. Mar. Biol. 152 (2), 405-414.

Borum, J., Duarte, C.M., Krause-Jensen, D., Greve, T.M., 2004. European Seagrasses: An Introduction to Monitoring and Management. The M\&MS Project.

Boudouresque, C.F., Bernard, G., Pergent, G., Shili, A., Verlaque, M., 2009a. Regression of Mediterranean seagrasses caused by natural processes and anthropogenic disturbances and stress: a critical review. Bot. Mar. 395.

Boudouresque, C.F., Bernard, G., Pergent, G., Shili, A., Verlaque, M., 2009b. Regression of Mediterranean seagrasses caused by natural processes and anthropogenic disturbances and stress: a critical review. Bot. Mar. 52 (5), 395-418.

Bryars, S., Collings, G., Miller, D., 2011. Nutrient exposure causes epiphytic changes and coincident declines in two temperate Australian seagrasses. Mar. Ecol. Prog. Ser. 441, 89-103.

Burkholder, J.M., Mason, K.M., Glasgow, H.B.J., 1992. Water-column nitrate enrichment promotes decline of eelgrass Zostera marina: evidence from seasonal mesocosm experiments. Mar. Ecol. Prog. Ser. 81, 163-178.

Burkholder, J.M., Tomasko, D.A., Touchette, B.W., 2007. Seagrasses and eutrophication J. Exp. Mar. Biol. Ecol. 350 (1-2), 46-72.

Cabaço, S., Machás, R., Vieira, V., Santos, R., 2008. Impacts of urban wastewater discharge on seagrass meadows (Zostera noltii). Estuar. Coast. Shelf Sci. 78 (1), 1-13.

Cabaco, S., Ferreira, C., Santos, R., 2010. Population dynamics of the seagrass Cymodocea nodosa in Ria Formosa lagoon following inlet artificial relocation. Estuar. Coast. Shelf Sci. 87 (4), 510-516.

Ceccherelli, G., Cinelli, F., 1997. Short-term effects of nutrient enrichment of the sediment and interactions between the seagrass Cymodocea nodosa and the introduced green alga Caulerpa taxifolia in a Mediterranean bay. J. Exp. Mar. Biol. Ecol. 217 (2), 165-177.

Dennison, W.C., 1987. Effects of light on seagrass photosynthesis, growth and depth distribution. Aquat. Bot. 27 (1), 15-26.

Durako, M.J., Kunzelman, J.I., 2002. Photosynthetic characteristics of Thalassia testudinum measured in situ by pulse-amplitude modulated (PAM) fluorometry: methodological and scale-based considerations. Aquat. Bot. 73, 173-185.

Erftemeijer, P.L.A., Stapel, J., Smekens, M.J.E., Drossaert, W.M.E., 1994. The limited effect of in situ phosphorus and nitrogen additions to seagrass beds on carbonate and terrigenous sediments in South Sulawesi, Indonesia. J. Exp. Mar. Biol. Ecol. 182 (1), 123-140.
Ferdie, M., Fourqurean, J.W., 2004. Responses of seagrass communities to fertilization along a gradient of relative availability of nitrogen and phosphorus in a carbonate environment. Limnol. Oceanogr. 49 (6), 2082-2094.

Filho, G.M.A., Creed, J.C., Andrade, L.R., Pfeiffer, W.C., 2004. Metal accumulation by Halodule wrightii populations. Aquat. Bot. 80 (4), 241-251.

Foy, C.D., Chaney, R.L., White, M.C., 1978. The physiology of metal toxicity in plants. Annu. Rev. Plant Physiol. 29, 511-566.

Govindjee, R., 1995. Sixty-three years since Kautsky: chlorophyll a fluorescence. Aust. J. Plant Physiol. 22 (2), 131-160.

Govindjee, R., 1999. On the requirement of minimum of four versus eight quanta of light for the evolution of one molecule of oxygen in photosynthesis: a historical note. Photosynth. Res. 59, 249-254.

Jepson, P.C., Sherratt, T.N., 1996. The dimensions of space and time in the assessment of ecotoxicological risks. In: Baird, D.J., Maltby, L., Greig-Smith, P.W., Douben, P.E.T. (Eds.), ECOtoxicology: Ecological Dimensions. Chapman and Hall, London, pp. 43-54.

Kelaher, B.P., Van Den Broek, J., York, P.H., Bishop, M.J., Booth, D.J., 2013. Positive responses of a seagrass ecosystem to experimental nutrient enrichment. Mar. Ecol. Prog. Ser. 487, 15-25.

Kenworthy, J.W., Fonseca, M.S., 1992. The use of fertilizer to enhance growth of transplanted seagrasses Zostera marina L. and Halodule wrightii Aschers. J. Exp. Mar. Biol. Ecol. 163 (2), 141-161.

Klerks, P.L., Weis, J.S., 1987. Genetic adaptation to heavy metals in aquatic organisms: a review. Environ. Pollut. 45 (3), 173-205.

Kraemer, G.P., Hanisak, M.D., 2000. Physiological and growth responses of Thalassia testudinum to environmentally-relevant periods of low irradiance. Aquat. Bot. 67 (4), 287-300.

Lee, K.-S., Dunton, K.H., 1997. Effect of in situ light reduction on the maintenance, growth and partitioning of carbon resources in Thalassia testudinum banks ex Künig. J. Exp. Mar. Biol. Ecol. 210 (1), 53-73.

Lee, K.S., Dunton, K.H., 1999. Influence of sediment nitrogen-availability on carbon and nitrogen dynamics in the seagrass Thalassia testudinum. Mar. Biol. 134 (2), 217-226.

Lee, K.-S., Park, S.R., Kim, Y.K., 2007. Effects of irradiance, temperature, and nutrients on growth dynamics of seagrasses: a review. J. Exp. Mar. Biol. Ecol. 350 (1-2), 144-175.

Leoni, V., Pasqualini, V., Pergent-Martini, C., Vela, A., Pergent, G., 2006. Morphological responses of Posidonia oceanica to experimental nutrient enrichment of the canopy water. J. Exp. Mar. Biol. Ecol. 339 (1), 1-14.

Leoni, V., Vela, A., Pasqualini, V., Pergent-Martini, C., Pergent, G., 2008. Effects of experimental reduction of light and nutrient enrichments ( $\mathrm{N}$ and $\mathrm{P}$ ) on seagrasses: a review. Aquat. Conserv. Mar. Freshwat. Ecosyst. 18 (2), 202-220.

Longstaff, B.J., Dennison, W.C., 1999. Seagrass survival during pulsed turbidity events: the effects of light deprivation on the seagrasses Halodule pinifolia and Halophila ovalis. Aquat. Bot. 65 (1), 105-121.

Longstaff, B.J., Loneragan, N.R., O'Donohue, M.J., Dennison, W.C., 1999. Effects of light deprivation on the survival and recovery of the seagrass Halophila ovalis (R. Br.) Hook. J. Exp. Mar. Biol. Ecol. 234 (1), 1-27.

Macinnis-Ng, C.M.O., Ralph, P.J., 2002. Towards a more ecologically relevant assessment of the impact of heavy metals on the photosynthesis of the seagrass, Zostera capricorni. Mar. Pollut. Bull. 45, 100-106.

Macinnis-Ng, C.M.O., Ralph, P.J., 2004a. In situ impact of multiple pulses of metal and herbicide on the seagrass, Zostera capricorni. Aquat. Toxicol. 67, 227-237.

Macinnis-Ng, C.M.O., Ralph, P.J., 2004b. Variations in sensitivity to copper and zinc among three isolated populations of the seagrass, Zostera capricorni. J. Exp. Mar. Biol. Ecol. 302, 63-83.

Malea, P., Kevrekidis, T., 2013. Trace element (Al, As, B, Ba, Cr, Mo, Ni, Se, Sr, Tl, U and $\mathrm{V})$ distribution and seasonality in compartments of the seagrass Cymodocea nodosa. Sci. Total Environ. 463-464, 611-623.

Malea, P., Haritonidis, S., Kevrekidis, T., 1995. The short-term uptake of copper by the two parts of the seagrass Halophila stipulacea (Forsk.) Aschers. and leaf-cells viability. Resenius Environ. Bull. 4 (2), 117-122.

Malea, P., Adamakis, I.-D.S., Kevrekidis, T., 2013a. Microtubule integrity and cell viability under metal $(\mathrm{Cu}, \mathrm{Ni}$ and $\mathrm{Cr}$ ) stress in the seagrass Cymodocea nodosa. Chemosphere 93 (6), 1035-1042.

Malea, P., Adamakis, I.-D.S., Kevrekidis, T., 2013b. Kinetics of cadmium accumulation and its effects on microtubule integrity and cell viability in the seagrass Cymodocea nodosa. Aquat. Toxicol. 144-145, 257-264.

Marín-Guirao, L., Ruiz, J.M., Sandoval-Gil, J.M., Bernardeau-Esteller, J., Stinco, C.M., Meléndez-Martínez, A., 2013. Xanthophyll cycle-related photoprotective mechanism in the Mediterranean seagrasses Posidonia oceanica and Cymodocea nodosa under normal and stressful hypersaline conditions. Aquat. Bot. 109, 14-24.

Masini, R.J., Cary, J.L., Simpson, C.J., McComb, A.J., 1995. Effects of light and temperature on the photosynthesis of temperate meadow-forming seagrasses in Western Australia. Aquat. Bot. 49 (4), 239-254.

Mvungi, E.F., Mamboya, F.A., 2012. Photosynthetic performance, epiphyte biomass and nutrient content of two seagrass species in two areas with different levels of nutrients along the Dar es Salaam coast. Afr. J. Mar. Sci. 34 (3), 323-330.

Oliva, S., Mascaro, O., Llagostera, I., Perez, M., Romero, J., 2012. Selection of metrics based on the seagrass Cymodocea nodosa and development of a biotic index (CYMOX) for assessing ecological status of coastal and transitional waters. Estuar. Coast. Shelf Sci. (0).

Orfanidis, S., Panayotidis, P., 2005b. Implementation of Water Framework Directive (WFD) for coastal waters by using the Ecological Evaluation Index-EEI: the case of Kavala's and Maliakos Gulfs, Greece. Proceedings 12th Panhellenic Congress Ichthyologists, Drama, Greece, pp. 237-240.

Orfanidis, S., Panayotidis, P., Siakavara, A., 2005. Benthic macrophytes: main trends in diversity and distribution. In: Papathanasiou, V., Zenetos, A. (Eds.), State of the Hellenic Marine Environment. HCMR Publishing, Athens, pp. 226-235. 
Orfanidis, S., Papathanasiou, V., Gounaris, S., Theodosiou, T., 2010. Size distribution approaches for monitoring and conservation of coastal Cymodocea habitats. Aquat. Conserv. Mar. Freshwat. Ecosyst. 20 (2), 177-188

Orfanidis, S., Papathanasiou, V., Zambounis, A., Tsioli, S., Kupper, F., Brown, M. Exadactylos, A., 2014. Cymodocea nodosa community as a bioindicator of eutrophication in North Aegean Sea: focus on structural, functional and genetics components. ECOST Workshop, Naples, Italy.

Orth, R.J., Carruthers, T.J.B., Dennison, W.C., Duarte, C.M., Fourqurean, J.W., Heck, K.L., Hughes, A.R., Kendrick, G.A., Kenworthy, W.J., Olyarnik, S., Short, F.T., Waycott, M., Williams, S.L., 2006. A global crisis for seagrass ecosystems. Bioscience 56 (12), 987-996.

Ouzounidou, G., 1993. Changes in variable chlorophyll fluorescence as a result of Cutreatment: dose-response relations in Silene and Thlaspi. Anglais 29 (3), 455-462.

Ouzounidou, G., 1994. Copper-induced changes on growth, metal content and photosynthetic function of Alyssum montanum L. plants. Environ. Exp. Bot. 34 (2), 165-172.

Ouzounidou, G., Eleftheriou, E.P., Karataglis, S., 1992. Ecophysical and ultrastructural effects of copper in Thlaspi ochroleucum (Cruciferae). Can. J. Bot. 70 (5), 947-957.

Papathanasiou, V., 2013. Cymodocea nodosa as a bioindicator of coastal habitat quality: an integrative approach from organism to community scale. School of Marine Science and Engineering, University of Plymouth, Plymouth.

Pergent-Martini, C., Pergent, G., 2000. Marine phanerogams as a tool in the evaluation of marine trace-metal contamination: an example from the Mediterranean. Int. J. Environ. Pollut. 13, 126-147.

Prasad, M.N.V., Strzalka, K., 1999. Impact of heavy metals on photosynthesis. In: M.N.V. P., J. H. (Eds.), Heavy Metal Stress in Plants. Springer, Berlin, pp. 117-138.

Ralph, P.J., 1999. Light-induced photoinhibitory stress reponses of laboratory-cultured Halophila ovalis. Bot. Mar. 11.

Ralph, P.J., Burchett, M.D., 1995. Photosynthetic responses of the seagrass Halophila ovalis (R. Br.) Hook. f. to high irradiance stress, using chlorophyll a fluorescence. Aquat. Bot. $51(1-2), 55-66$

Ralph, P.J., Burchett, M.D., 1998. Photosynthetic response of Halophila ovalis to heavy metal stress. Environ. Pollut. 103 (1), 91-101.

Ralph, P.J., Gademann, R., 2005. Rapid light curves: a powerful tool to assess photosynthetic activity. Aquat. Bot. 82 (3), 222-237.

Ralph, P.J., Tomasko, D., Moore, K., Seddon, S., Macinnis-Ng, C.M.O., 2006. Human impacts on seagrasses: eutrophication, sedimentation and contamination. In: Larkum, A.W.D., Orth, R.J., Duarte, C. (Eds.), Seagrass: Biology, Ecology and Conservation. Springer, Dordrecht, pp. 567-593.

Ralph, P.J., Durako, M.J., Enriquez, S., Collier, C.J., Doblin, M.A., 2007. Impact of light limitation on seagrasses. J. Exp. Mar. Biol. Ecol. 350, 176-193.

Ramirez Garcia, P., Terrados, J., Ramos, F., Lot, A., Ocana, D., Duarte, C.M., 2002. Distribution and nutrient limitation of surfgrass, Phyllospadix scouleri and Phyllospadix torreyi, along the Pacific coast of Baja California (Mexico). Aquat. Bot. 74 (2), 121-131.
Reyes, J., Sanson, M., Afonso-Carrillo, J., 1995. Distribution and reproductive phenology of the seagrass Cymodocea nodosa (Ucria) Ascherson in the Canary Islands. Aquat. Bot. 50 (2), 171-180.

Short, F.T., 1987. Effects of sediment nutrients on seagrasses: literature review and mesocosm experiment. Aquat. Bot. 27 (1), 41-57.

Short, F.T., Wyllie-Echeverria, S., 1996. Natural and human-induced disturbance of seagrasses. Environ. Conserv. 23 (1), 17-27.

Short, F.T., Burdick, D.M., Kaldy, J.E., 1995. Mesocosm experiments quantify the effects of eutrophication on eelgrass, Zostera marina. Limnol. Oceanogr. 40 (4), 740-749.

Sylaios, G., Stamatis, N., Kamidis, N., Markou, D., Stergiou, D., 2004. Monitoring, Assessment and Evaluation of the Coastal Marine Environment of Kavala Gulf. NAGREF-FRI, Kavala, p. 281.

Sylaios, G., Stamatis, N., Kallianiotis, A., Vidoris, P., 2005. Monitoring water quality and assessment of land-based nutrient loadings and cycling in Kavala Gulf. Water Resour Manag. 19 (6), 713-735.

Touchette, B.W., Burkholder, J.M., 2000. Review of nitrogen and phosphorus metabolism in seagrasses. J. Exp. Mar. Biol. Ecol. 250 (1), 133-167.

Tuya, F., Viera-Rodríguez, M.A., Guedes, R., Espino, F., Haroun, R., Terrados, J., 2013. Seagrass responses to nutrient enrichment depend on clonal integration, but not flow-on effects on associated biota. Mar. Ecol. Prog. Ser. 490 (2).

Tuya, F., Ribeiro-Leite, L., Arto-Cuesta, N., Coca, J., Haroun, R., Espino, F., 2014. Decada changes in the structure of Cymodocea nodosa seagrass meadows: natural vs. human influences. Estuar. Coast. Shelf Sci. 137, 41-49.

Udy, J.W., Dennison, W.C., 1997. Growth and physiological responses of three seagrass species to elevated sediment nutrients in Moreton Bay, Australia. J. Exp. Mar. Biol. Ecol. 217 (2), 253-277.

Udy, J.W., Dennison, W.C., Long, W.J.L., McKenzie, L.J., 1999. Responses of seagrass to nutrients in the Great Barrier Reef, Australia. Mar. Ecol. Prog. Ser. 185, 257-271.

Walker, D.I., Campey, M.L., Kendrick, G.A., 2004. Nutrient dynamics in two seagrass species, Posidonia coriacea and Zostera tasmanica, on Success Bank, Western Australia. Estuar. Coast. Shelf Sci. 60 (2), 251-260.

Walker, D.I., Kendrick, G.A., McComb, A.J., 2006. Decline and recovery of seagrass ecosystems-the dynamic change. In: Larkum, A.W.D., Orth, R.J., Duarte, C.M. (Eds.), Seagrass: Biology, Ecology and Conservation. Springer, Dordrecht, pp. 551-565.

Worm, B., Reusch, T.B.H., 2000. Do nutrients availability and plant density limit seagrass colonization in the Baltic Sea? Mar. Ecol. Prog. Ser. 200, 159-166.

Xeidakis, G., Georgoulas, A., Kotsovinos, N., Delimani, P., Varaggouli, E., 2010. Environmental degradation of the coastal zone of the west part of Nestos river delta, $\mathrm{N}$. Greece. 12th International Congress of the Geological Society, Patra, pp. 1074-1083. 